\title{
Working the Self: Truth-Telling in the Practice of Alcoholics Anonymous
}

\section{Fredrik Palm ${ }^{1}$ iD}

Accepted: 6 December 2020 / Published online: 2 February 2021

(c) The Author(s) 2021

\begin{abstract}
This article interrogates twelve step practice within Alcoholics Anonymous (AA) from the perspective of Foucault's later work on governance, truth-telling and subjectivity. Recent critical studies of addiction tend to view self-help cultures like that of AA and related twelve step programs as integral parts of contemporary power/ knowledge complexes, and thus as agents of the modern "will to knowledge" that Foucault often engages with. In line with the widespread Foucauldian critique of governmentality, addiction self-help culture is thus conceived as one that primarily reproduces abstract, neoliberal norms on health and subjectivity. The argument put forward in this article aims to upset this framework attending to a number of features of twelve step practice that, arguably, bear striking resemblances to Foucault's later discussions of ethics, care of self and truth-telling. In this, it is suggested that a close study of AA practices, might interrupt assumptions about contemporary addiction discourse and its relationship to issues of truth and power often reproduced in Foucauldian critiques.
\end{abstract}

Keywords Alcoholics anonymous · Alcoholism · Addiction · Foucault · Truthtelling · Care of self

Fredrik Palm

fredrik.palm@soc.uu.se

1 Department of Sociology, Uppsala University, Box 624, SE-751 26 Uppsala, Sweden 


\section{Introduction}

Most contemporary scholars of addiction would probably agree that truth is a lost cause in the discourse of Alcoholics Anonymous (AA). ${ }^{1}$ While its historical influence in scientific, therapeutic and self-help discourses is widely recognized, few scientific discussions of alcoholism and addiction today credit its "practical wisdom" with any validity. If anything, its institutional success - as indicated by its continuing importance in nonprofessional, self-help culture; that it keeps attracting individuals with a desire to stop drinking; that its Twelve Step practice of sharing has seeped into the everyday culture of contemporary society, etc.-is commonly interpreted as a consequence of its relative efficiency within a broader nexus of biopolitical power. In particular, critical scholars drawing on Michel Foucault regularly consider AA as part of a larger addiction discourse that governs individuals along the lines of moral codes and historical processes of normalization typical of the modern will to knowledge. In line with Nikolas Rose's understanding of the Foucauldian notion of governmentality, this critique is highly suspicious of subjectivist discourse. And if alcoholism early on was defined as "a disease of the will," this is often interpreted as indicating a modern form of soft governance organized around the celebration of individuality, responsibility, and control (Valverde 1998). Providing knowledge of health and pathology, alcoholism and addiction become "technologies of the self" "imbued with aspirations for the shaping of conduct" that help subordinating individuals to what is posited as proper behavior (Rose 1999: 52; Valverde 1998: 15). Addiction, hence, is seen as a "powerful therapeutic and political discourse which classifies, normalizes and disciplines subjects" (Fraser, Moore, \& Keane 2014: 5).

There is, however, a tendency in this critique to overemphasize aspects of addiction discourse that confirm its association with governmentality and bio-politics, and to neglect elements of addiction discourse that do not fit this general picture. This is not least the case with efforts among these scholars to approach Twelve step practice (Valverde 1998; Keane 2002). Against this, it is here argued that AA's "talking cure" - its particular way of situating alcoholism in close proximity to issues of interaction and speech - deserves more nuanced attention by Foucauldian and other critical scholars of addiction. In contrast to the steady progress of the field of addiction along the hegemonic lines of evidence-based medical practice, neuroscientific knowledge, diagnostic manuals, etc., AA holds on to a practice that not only remains surprisingly similar to what it was in the 1940s, but also ties well-being to a simple

\footnotetext{
1 Founded in Akron, Ohio, in the 1930s, Alcoholics Anonymous with its Twelve Step program for recovery has been vital for modern discourse and practice in the area of addiction. As stated in the Twelve Traditions that regulate AA, it is explicitly nonprofessional, self-supporting, and apolitical, with the sole purpose of collectively supporting its members' desire to abstain from drinking. Modelled on the American Christian Oxford Group it states a spiritual solution to alcoholism. Central for AA is its practice of sharing, its egalitarian rejection of leaders, and-unsurprisingly-its insistence on anonymity. Although heavily associated with American society and culture, AA and its sister organizations (Narcotics Anonymous, Al-Anon, Sex and Love Addicts Anonymous, Overeaters Anonymous, etc.) are today represented all around the world, and AA alone currently counts over 2 million members and 120000 groups worldwide (Alcoholics Anonymous 2018).
} 
practice of open sharing of experience. This marks an orientation to truth and transparency that at first glance appears to confirm the standard thesis of governmentality. However, it is here suggested that a closer study of the structure of AA practice may alter this impression radically, insofar as the role it gives to speech and truthtelling in fact appears to have the potential of undermining governance. It is also argued that the keys to such an alternative view are provided by Foucault himself.

Based on Foucault's later work on the more general problematic of the will to truth, the article offers an alternative Foucauldian approach to addiction discourse than that suggested by critical addiction studies. In a way, Foucault's turn to the will to truth of course represented a continuation of his analysis of the modern will to knowledge. But it also widened the scope of Foucault's investigation, and in particular suggested a more sympathetic approach to practices of truth-telling (veridiction). In response to an increased awareness of a need to formulate "a space of knowledge simultaneously outside formations of power and yet capable of undermining them" (Rabinow 1997: xvii), he came to pay more attention to truth-telling as a vital element of counter-conduct and ethics of care. Particularly in Foucault's posthumously published lectures from the Collège de France, ${ }^{2}$ we observe a growing interest in practices of truth that resist power, and with this shift, he begins to disentangle truth from modern governance. Most importantly, this is done in his thorough discussions of the Greek notion of parrhessia as honest, open and fearless truth-telling, that closely ties into his analysis the ethical care of self and "aesthetics of existence" (Foucault 2005, 2010, 2011).

The implications of this new direction in Foucault's late work, are still debated among Foucauldian scholars. In political, feminist, and queer theory, numerous studies draw on his ethics of care and discussion of parrhēsia in the development of critical theory and notions on political resistance in contemporary society (Bech Dyrberg 2016; Dean 2009; Hardt 2010; Heyes 2018; Oksala 2016; Prozorov 2017). Such approaches still attend to the decentralized character of modern governmentality, and its "conduct of conduct". Yet, they also recognize the need to rethink what resistance, critique, and political action might entail in a situation where the dominant mode of power is characterized by a critical ethos (Folkers 2016: 19). Thus, Cressida Heyes (2018) in her article on awareness in somatic practices like yoga, insists on the ambiguous role of these practice in relation to governmentality insofar as they both allow for normalizing judgement, and more radical transformations of lived experience through truth-telling. In this way, truth-telling is not automatically associated with power, but also contains a potential for counter conduct.

In a related effort, this article offers an elaborated account of various tactical elements of AA practice, relating these to Foucault's descriptions of parrhēsiastic truthtelling. The claim is not that AA practice is outside or straightforwardly opposed to governance. Like any other modern practice it cannot be. But a close study of particular tactical elements and technologies of the self involved in AA practice raises

\footnotetext{
${ }^{2}$ In particular the final seminar The Courage of Truth: The Government of Self and Others, which most extensively develops the Greek notion of parrhēsia as honest and fearless truth-telling, will be important in this paper.
} 
similar questions as Heyes' analysis does about the nature of the authority involved and its relationship to biopolitical governance. ${ }^{3}$ In the following, this article closely analyzes a number of core elements of AA practice and situates them in relation to these latter thoughts in Foucault. Thus, it aims to wrest this particular branch of addiction discourse from the monolithic understanding of power and authority that Foucauldian interrogations of addiction up until now often have confirmed univocally.

\section{Authority in the Game of AA}

A prominent feature of AA practice is its highly regulated organization, which the alcoholic needs to accept in order to become a member. The question here is how we can understand the role of these regulations in the production of truth in AA. Is this role as some have argued merely about a fostering of dogmatism, or, are there other consequences of the regime that they establish? It is clear that AA practice presupposes a certain grade of subordination to its framework insofar as it puts a demand on the individual to adhere to its method and rules, and to do so in an honest way. This, however, is also true for the parrhēsiastic game as Foucault outlines it. As he notes, it is originally based on a pact of frankness that obliges the participants to accept the moral duty of care (Foucault 2011: 128). A minimal amount of authority is therefore given to this game by the very fact that one has agreed to play it. In Foucault's description of Socratic discourse in Plato's dialogue the Laches, it is one of the key players in the dialogue, Nicias, who describes the method of Socrates' game that he and Laches are obliged to agree to if they are to enter the game, most importantly, the demand to tell the truth (2011: 142). The subordination to the game as such is thus not what ultimately decides whether the game produces obedience or something that disrupts it. The decisive element rather lies in the way in which the game relates to the ethical dimensions of the care of self. Unlike governmentality, practices of care of self and parrhēsia are characterized by the way in which they refuse authority based on the abstract will to knowledge, and the hierarchical structure organized around a master figure "who knows" (Hadot 2009: 123). Although produced by specific institutional or organizational arrangements oriented to truth, parrhēsiastic authority rejects the master's hierarchical monopoly on truth, and instead turns to an authority given to someone who lives in accordance with his teachings (Foucault 2011: 148).

\footnotetext{
${ }^{3}$ For instance, the moral inventory and monitoring of ones' own behavior on a daily basis outlined in the fourth step of AA, are probably influenced by early forms of Protestant self-help examination like the diary keeping practiced in the Presbyterian Church in the eighteenth and nineteenth centuries (Mutch 2015: 277). This suggests precisely a form of confessional culture, which according to Foucault's analysis works to secure the presence of pastoral morality in the everyday Christian life. However, when Foucault notes that similar forms of autobiographical self-inspection and narratives of the self were present already in Greek practices of care of self-and therefore not particular to modern society-this is indicative of a quite different approach to AA's daily inventory (Foucault 1997: 276; Luque 2018).
} 
Indeed, it is this very opposition between, on the one hand, an authoritative truth based on an abstract master-knowledge, and, on the other hand, a more egalitarian truth-telling, which organizes Foucault's discussion of the Christian pastoral institution in his seminar on Security, Territory, Population (2007). According to Foucault, there are two fundamental elements in the emergence of the pastoral institution in the tenth century, first, the development of the dimorphism that distinguishes the clergy from the laity, and, second, the special sacramental power with which the pastorate endows the clergy (2007: 202ff.). These institutional features prefigure modern governance and its bureaucratic division between experts and lay people. They also make religious practice reliant on a "judicial model" based on mandatory confession and a belief in the Purgatory. This affected the authority that the clergy executed, insofar as it was increasingly involved in procedures of judgment and punishment. Under this judicial regime, the pastoral institution then began to demand strict obedience from its followers, and forced its subjects to renounce their will. In contrast to the pastoral institution, Foucault describes a number of tactical elements of counter-conduct utilized against the pastoral structures of power, and its fundamental clergy-laity hierarchy. These elements of counter-conduct not only interrupt Christian governance, but do so from within Christianity itself. One important example in Foucault's argument is that of asceticism, which in contrast to the pastoral regime demands from its followers a total exercise of self on self that undermines the authority of the pastorate. Taking on the role to guide oneself through various exercises, the ascetic refuses the dimorphism that structures pastoral discourse, as well as, its hierarchy of obedience (Foucault 2007: 205ff.).

Comparing these discussions of the parrhēsiastic game and counter-conduct in Foucault, with the formal structure of AA practice as expressed in meeting rules and the so-called Twelve Traditions of AA, we can discern how it as a game or pact establishes certain values and goals as legitimate while others are dismissed. Most importantly, their function appears to be to protect AA's orientation toward common well-being and recovery as AA interprets these, as well as, to create egalitarian relations between its members. If we first turn to the regulation of the meeting setting, we note how they are characterized by a strictly institutionalized order of activities. On the one hand, there are formalized opening and closing episodes that give the meeting an essentially rigid and impersonal structure, and, on the other hand, sharing episodes that allow for interaction and exchange of personal experience among meeting participants (O'Halloran 2008: 129-52). Part of this order are negative rules on communication during sharing, for instance, to not use expert discourse, give advice, cross-talk, etc. As Mäkelä et al. (1996) stated in a cross-country study of AA meetings, the resistance against religious doctrines, scientific theories, causal explanation, and psychological interpretation can be considered as near-universal features of the AA meeting. Such regulations then clarify the discourse, blocking the influence of abstract expert knowledge in meetings, and orienting the collective attention of the meeting toward the sharing of concrete experiences of alcoholism and recovery.

Second, we have regulations as these are formulated in the Twelve Traditions whose role are to provide guidelines for the organization of AA, both on a local and global level. The positive function of these traditions is to organize the game 
around values like "common well-being," "personal recovery" and the authority of "a loving God". Such traditions then specify individual recovery, collective welfare, and the higher power, etc. as legitimate concerns of AA. Another similarly specified value is that of "anonymity" that not only protects individual members, but also prohibits any personal appropriation of the organization (Bateson 1972: 334; O'Halloran 2008: 43). In this sense, however, a significant function of the traditions that claim anonymity (Tradition 11 and 12) is negative, and serves to protect $\mathrm{AA}$ as a game from interests that might compete with its central positive values. In the same manner, other traditions state that AA "should remain forever non-professional" (Trad. 8), "ought never be organized" (Trad. 9), and "our leaders... do not govern" (Trad. 2). These particular statements clearly protect the non-expert character of AA discourse, and the authority of individual members and groups, blocking the emergence of new versions of dimorphism and expert rule within AA. In short, their role is to preserve the flat, anti-hierarchic structure of AA, and keep it egalitarian in terms of power. As stated, there are also regulations of external relations stating that AA "ought never endorse, finance or lend the AA name to any related facility or outside enterprise," "ought to be fully self-supporting, declining outside contributions," "has no opinion on outside issues". These traditions typically block the introduction of competing stakes into the AA game, in particular those of economy, politics and public opinion, rendering such interests illegitimate.

In order to participate in the game of AA with authority the member must then accept certain non-negotiable rules. An important portion of such rules consists of the negative regulations that seem to protect AA from external influence from the state, market, religious institutions, as well as, medicine and other scientific knowledge. They allow AA to organize itself independently of bodies of power typically associated with governance in Foucault's argument. While AA reproduces its version of addiction discourse, this is therefore not necessarily done in a way that fits bio-power. In the same manner, negative regulations-as in the case of meeting rules-prohibit antagonist relations within AA, and protect each member's right to talk without being interrupted, advised or questioned by other members. This counteracts a meeting dynamic in which some members informally take on the role of informal experts. In sum, it then appears as if these rules, in a similar manner as in other forms of counter-conduct that Foucault discusses, impede the establishing of expert rule and dimorphic hierarchies in AA practice.

It is interesting to note how effective these quite rudimentary rules of conduct seem to have been, insofar as the practice of AA as an egalitarian game united around one common goal has persisted largely unaltered ever since its formation in the 1940s. If then, for instance, its disease concept appears as unfazed by different developments in medicine and psychiatry, this is probably a sign of a certain grade of epistemological immunity from exterior influences from scientific, religious, or, economic discourses and interests, produced by these regulations. But these regulations also guard against hierarchies of power being established within AA, both on the level of local meetings, and in terms of a potential emergence of dimorphism between representatives and leaders of AA and ordinary members. These institutional features of AA seem difficult to align with the hypothesis that regulations in addiction discourse necessarily support the normative machinery of modern 
bio-politics. Negative regulations rather appear to defend the particularity of the AA-game from such authority. In this, AA clearly relies both on rules and abstract notions like disease and identity. Yet, this does not automatically suggest that it is part of a metaphysical or totalizing discourse. Rather, one could argue that it is precisely these rules and notions that allow something concrete to unfold and gain authority within AA. In the following I will suggest that this something that unfolds in the practice of AA and produces its authoritative truth, is the experience of alcoholism and recovery and the ongoing effort to account for and share this experience among AA members.

\section{The Authority of Shared Experience}

If the game of AA orients practice towards its member's collective well-being and recovery and thus organizationally confers authority to these goals, it is the written and oral discourse of AA that realize the latter. These discursive devices socialize the newcomer and define not only AA as a practice, but, moreover, the problem of alcoholism, as well as the solution to it. The central feature of this machinery is the element of sharing, as expressed both by written and oral accounts of lifestories. For instance, more than half of The Big Book of Alcoholics Anonymous is made up of written life-stories, all following the narrative of "alcoholic life-hitting bottom-coming to AA". Even more important, however, is the practice of sharing in AA meetings. This sharing-although also involving life story-telling-has a much broader scope and often involves members concrete dealing with individual experience of step work and recovery on a daily basis. Despite this difference, these practices of accounting and sharing have the common function of focusing AA's attention on the ongoing experience of individual members.

This focus on an ongoing accounting for one's lived experience resembles Foucault's description of parrhēsia as an exercise of truth in the concrete everyday lives of individuals. To return to Nicias' description of the Socratic game in the Laches as Foucault addresses this dialogue, Nicias argues that Socrates forces the participant to make an honest or frank account of oneself, of the life one leads now and has led in the past. As stated, it is important to Foucault that Socratic discourse is not one in which the participant can expect to learn a specific truth or pre-existing body of knowledge (Socrates "knows nothing"). It is rather a process in which the participant is forced to scrutinize what he holds to be true and how he lives his life, a test of the relation between himself and logos, life and word. ${ }^{4}$ According to Nicias description, it is a game of testing in which one will continuously be questioned by Socrates as one makes this account. In this game, Socrates takes on the structural function of the basanos, the touchstone, which allows the participants to engage themselves in

\footnotetext{
${ }^{4}$ It is this process of testing that gives the game its characteristic quality, and Foucault is careful to distinguish it from the questioning of the court and technical teaching (Foucault 2011: 144)-two examples whose authority like that of (post-pastoral) governance relies on expert rule, dimorphism and hierarchy.
} 
a process of distinction, evaluating their lives by telling good from bad (Foucault 2011: 142-5).

Now, while AA also encourages members to make an honest account of themselves, their life and the beliefs that underlie the alcoholic life, this is done through a game with a very different structure than that of Socratic discourse. AA's method is first of all not one of dialogical questioning. Its order of interaction instead encourages a form of self-reflection based on identification between individual and collective experience. It is a self-testing process paralleled by and related to other members' self-testing, where the increased understanding of one's alcoholic behavior, emerges as an effect of shared experience of alcoholism and recovery with other alcoholics. While the concrete practice of the meeting hence leaves little space for explicit questioning of the subject by others, there is nevertheless a dialectic between individual and collective that introduces an element of evaluation and self-questioning. On the one hand, the member works the different steps on her own. She admits to being powerless over alcohol, surrenders to a higher power, etc. Some of these steps state more concrete tasks of self-reflection. For instance, the vital fourth step challenges the alcoholic to "make a searching and fearless moral inventory" of her life, while the tenth step restates the need of continued inventory while adding "... and when we were wrong promptly admitted it". On the other hand, this individual step work is situated in the collective discourse of AA, where experiences of step work and recovery are regularly shared. This dialectics fosters a collective gaze in the individual member that works as an instance of self-questioning.

Given this structure of AA discourse, it is not unlikely that AA discourse at least occasionally takes on the role as an abstract knowledge. If, as O'Halloran shows, the concrete phraseology of individual alcoholics as a rule draws heavily on both AA's literature and its oral tradition (O'Halloran 2008: 68), there is a real danger that AA knowledge is internalized and obediently passed on as abstract truths bluntly applied to the individual member's life. AA in this sense risks to conserve abstract understandings of one's life. It is among such fears that scholars sympathetic to AA have sometimes emphasized the pragmatism of AA, typically conveyed by AA slogans such as "Utilize, don't analyze," and "It works!" Although these standardized messages that members regularly draw on are often dismissed as dogmatic and to discourage individual thinking (Bufe 1998: 146), this defense sidesteps the question of the validity of AA's practical wisdom, instead focusing on its practical gains and results in terms of recovery (Tiebout 1947; White 1998). As Tiebout for instance argued, we might doubt the scientific value of alcoholism as a medical diagnosis, at the same time as we acknowledge that these truths are pragmatically decisive insofar as they motivate a clear break with drinking and a complete surrender to AA practice. That is, they should be accepted not because they state an objective truth, but because they work. O'Halloran and Denzin seem to share this view insofar as they underline that AA is not one of scientific knowledge, but "a programme for living," (O'Halloran 2008: 123; Denzin 1993: 51). It provides a number of useful steps for staying sober, rather than some systematic doctrine (O'Halloran 2008: 68). In this sense, it appears as if the primary appeal for the alcoholic would be that AA prompts a form of care of self. 
An unfortunate consequence of this argument, however, is that it implicitly appears to corroborate the claim that the value of AA's practice does not lie in its relation to truth. It is here that Foucault's idea of the intimate relation between parrhēsia and care of self allows an alternative reading that rather than avoiding the question of truth, makes it essential to AA practice. Because, insofar as attention in AA is directed to practice, this ultimately implies not a turning away from truth as such. The stake is rather a turning away from truth as an abstract, pre-existing body of knowledge, towards a process of truth-telling immersed in lived experience. That is, a shift from a dogmatic, passive internalization of an "objective" AA-knowledge, towards an active process of internalization where AA discourse becomes part of a lived becoming-truth. While AA pragmatism does away with a certain form of truth, it does not do away with truth as such. Its pragmatic suspicion against scientific truth is only the other side of a firm belief in lived truth-telling.

This pragmatic suspicion to abstract thinking and scientific discourse in fact shapes the very form that AA talk takes. AA truth-telling is not technically sophisticated, but shares with Socratic and Cynic parrhēsia a preference for simple and straightforward speech (Foucault 2011: 75). Like Socrates' suspicion against the seductiveness of skillful speakers, AA discourse is marked by the discursive norm of "keeping it simple" (O'Halloran 2008). Not only is the use of abstract, expert knowledge discouraged, but life story-telling, sharing and other talk are typically delivered in a direct manner that aims to include all members and stay close to mundane experience. The authority of its speech emerges not through elegant rhetoric, or, theoretical explanation, but through a simple rendering of life as it is. The function of slogans are-like the organization of AA practice-often to protect this direct speech from abstract rationalization. Again, slogans risk to be internalized as abstract, dogmatic truth, but such abstract internalization is not the ideal that AA encourages. This latter is instead one of perpetual testing-working the steps, and accounting for this work in meetings — of one's word in relation to one's life.

And if this concern in AA expresses itself in the focus on how each member concretely works the steps, it is a similar concern that explains Foucault's celebration of Cynic philosophy, and its particular way of life (bios kunikos) dedicated to truth-telling (Foucault 2011: 217). According to Foucault, Cynicism-although often thought of as a scandal in Greek thought (Foucault 2011: 231)-was deeply faithful to the Socratic themes of care of self, and true life. The bios kunikos was a life that constantly examined and tested the actual way one conducted one's existence (Foucault 2011: 159). Although AA practice cannot be said to produce scandal, it does produce a life in constant examination. Authoritative speech in AA is simply put one that conveys an ability of constantly testing and evaluating one's way of relating to self, others and the higher power, a talk whose rationality does not loose itself in abstract explanation, but remains grounded in the service of a care of self and others. In this sense, the ultimate aim of AA would be to establish a care of self, based on a performative truth-telling. While it is probable that each member enacts its discourse and tools more or less abstractly, truth proper in AA appears to emerge only in and through member's own lived experience of alcoholism and recovery. If this is correct, AA pragmatism does not avoid truth, but takes it as a core element in the process of allowing oneself to collectively appear as a subject freed from the 
dynamics of denial, isolation, hiding, shame, guilt, resentment, anger, self-pity, etc. To enforce a correspondence between word and life in one's life is ultimately not about adapting one's life to the doxa of AA (although, there is always an element of this), but to live a life of transparent and shameless reflection. A life situated in that which caused alcoholic behavior, rather than in constant struggle to deny or repress it.

Perhaps one might suggest that it is this will to truth about oneself (expressed in the readiness to honestly, fearlessly, and in a direct manner render one's present life) which pulls the alcoholic towards AA. This attitude of ongoing, honest translation of life into discourse would in this sense not be a means to an end, but rather an inherent feature of recovery that stands in stark contrast to an alcoholic life marked by loneliness, self-centeredness, shame, and distrust. In the acquisition of a dialogical view of one's life (O'Halloran 2008: 209), the member encounters an essentially social "cure" that demands her trust in a discourse solely warranted by the appearance that it works for other alcoholics who like Socrates seem to live in accordance with their discourse. What makes such a social cure possible is then precisely truth-telling, and thus it is ultimately the case that AA challenges the alcoholic to give up drinking for a life of truth. Unlike drinking, however, Foucault's work insists that such a life of truth does not only require arduous work and persistence, but furthermore courage and ethics. We should therefore not be surprised to see that AA discourse emphasizes the need of both courage and spiritual belief as support for the leap of faith that entering AA implies. As we will see, both of these pillars are also vital parts of parrhēsia as Foucault discusses them.

\section{Authority of Courage}

In The Courage of Truth (2011) Foucault argues that parrhēsiastic figures like Socrates derive their authority precisely from their fearlessness to live according to their teaching despite the dangers this might entail. This fearlessness is part of the answer to the ethical question that orients the Laches, of who one as a parent should entrust to educate (care for) one's children. What makes one suitable for this mission? According to the dialogue, it is the already mentioned ability to live according to one's teachings and to have the courage to put one's life at stake through parrhēsia that are vital. Socrates embodies this ideal as the one who dares to live a true life despite the dangers this may entail (2011: 74). If Socrates rational method lies in his game of questioning, his ethical act is to put the conventional life of Athens at stake, and thus to threaten this life. It is through this fearlessness that he paradoxically is trusted as the basanos. Hence, it is not a flawless theory but an attitude of courage to speak and live truthfully that is demanded from the one who is supposed to care, and that attracts the citizen to take part in his game of truth-telling.

In relation to AA, we should then ask whether we here have a truth that raises fear, that threatens alcoholic life, and as such demands courage from the member of AA? Overall, it appears as if truth-telling in AA conforms to Foucault's understanding of parrhēsia as being rooted in and part of a more original ethical decision of 
care. More specifically, AA truth-telling seems to be closely linked to an experience of not being able to take care of oneself, of life being unmanageable, and that one is powerless over alcohol. Truth-telling originates in a radical hit bottom experience, that calls for the alcoholic to think and act (Gros 2011: 388). According to AA, this experience of powerlessness undermines the last traces of certainty that supports the alcoholic self and thus paves the way for a life based on new principles.

This echoes Foucault's ideas on parrhēsia since truth in Socratic discourse is premised on uncertainty and a kind of non-knowledge. Socrates repeatedly insists to "know nothing," and in The Courage of Truth, Foucault posits the ability of "losing one's way" as a condition for ethical self-transformation (Davidson 2005: xxviii). As Davidson argues, parrhēsiastic practice-for Foucault-undermines the assumptions that the subject takes for granted in her life. It is only through this loss of way that parrhēsia produces what Foucault terms an "other life" and "other world". 5 The experience of powerlessness, as embodied in the privileged moment of hitting bottom, closely corresponds to this loss of one's way, and the undermining of what one has taken for granted in one's life. Indeed this experience is seen as crucial for recovery in AA in the sense that it makes possible the altering of one's life, and the willingness to put one's trust in the program. Although individually defined, the experience of hitting bottom must be sufficiently strong for the alcoholic not being able to shy away from his powerlessness, while an inadequate experience allows the alcoholic to shun its significance. The complete lack of hope and power allows for belief and change in AA.

This new life is moreover not one that resolves this lack by restoring a life of power, will and control. Lack is on the contrary a constitutive feature of recovery and AA epistemology, and phenomena like denial and relapse are here, if anything, linked to the illusion that lack has been somehow transcended in recovery. The desire for a complete recovery-that is, of being cured of alcoholism once and for all-marks the return of what in AA discourse is termed alcoholic pride. Recovery in contrast entails not only hitting bottom as such, but furthermore the maintenance of its memory. And in fact it is first with this act of memorizing that we can start talking of truth-telling in AA practice. Because, while hitting bottom is an experience of radical destabilization, it is also something which happens to or imposes itself on the alcoholic. It is not yet an act proper. First with the re-activation of this traumatic experience we can begin to discern something that resembles parrhēsia.

We should here ask whether this act of bearing witness to one's powerlessness, like parrhēsia, exposes the enunciator to any danger or risk (Foucault 2010: 56). Does it entail any cost or put anything at stake in her life? At this point we might look a bit closer at the role that denial plays according to AA. Simply put, denial protects the alcoholic drinker from the consequence of not being able to enjoy alcohol, and the solution that it has presented in the alcoholic's life for dealing with her present condition. As Denzin has argued it functions as a "bad faith" insofar as it allows "the alcoholic and his or her other [...] to escape the facticity of alcoholism by denying its existence" (Denzin 1993: 108). In contrast, the blunt enunciation "I

\footnotetext{
${ }^{5}$ Foucault here plays with the terms l'autrement and autre monde (Foucault 2011: 287).
} 
am x, and I am an alcoholic" undermines both denial and the alcoholic belief system. Although the institutional repetition of this utterance might appear evacuated of individuality and individual stakes, in the individual alcoholic's life the risk of losing the way of drinking is radical. And giving up drinking is in AA precisely seen as a necessary consequence of the experience of powerlessness that hitting bottom imposes on the alcoholic. The targeting of denial in the collective experience of recovery within AA attests to the size of this risk, as does the enormous effort that goes into sharing experiences of powerlessness in daily recovery. In fact, each component of AA practice-from acknowledging one's powerlessness over alcohol, to putting one's trust in the program and the higher power, making a fearless moral inventory, admitting to and sharing these wrongs in meetings, making amendments, and committing to the program as a lifelong process, etc.- - seem related to this danger. And the solution or alternative within AA appears to be precisely the constant and ascetic exercise of care, courage, and truth-telling. As Foucault notes apropos parrhēsia in early Christian asceticism, confidence in the program and God is not primarily a safety device but a radical challenge of conventional life that requires courage (Foucault 2011: 332).

Like the Cynic in Foucault, other members of AA do not only present the alcoholic with another life of ideal, true and authentic existence (Foucault 2011: 314), but with a life of loss and ascetic living. Although the particular "losing of one's way" takes different forms in these games (in AA it prefigures the game, in the Socratic game it is a result of it), none of them primarily offer a certain knowledge (Socrates knows nothing and refuses to give answers; AA points to effects). Old members gain authority by living a life based on an acceptance of loss of drinking and loss of control, as if this life does not entail any real loss, since there was no actual control—and thus no loss — in the first place. They show how loss can be the source for a new life, and embody acceptance and courage in a way that incites new members to surrender to the program and begin truth-telling, and step work. It is this experience of "true life" that inspires new members to a combat with alcohol that resembles the Cynic mission of combat comprising endurance, harshness towards oneself, suffering and acceptance of injustice, where blows are regarded as challenges that makes one great (Foucault 2011: 299). What is at stake here is not a harshness that subordinates the alcoholic to an apparatus of obedience, and that removes her from the realm of practical existence. It is not a life lived for another (after) life, where the authority over one's life is removed from the present life of the subject. Instead it is a life that Foucault associates with a feature of modern philosophy to reject authorities of knowledge and reinvents present life (Gros 2011: 388). And as Foucault argues this reinvented life is one that only can emerge as an essentially spiritual life.

\section{The Authority of Spirituality}

As Richard White (2014: 502) has pointed out, Foucault's care of self targets abstract beliefs in moral codes and the anomie of modern consumer-oriented lifestyle, by reclaiming a more spiritual way of life that cultivates itself through the 
ardent everyday practice of questioning, reflection and spiritual exercise. This emphasis on spirituality says something about what modern governance lacks. Foucault argues that modern thought and authority (power) are phenomena characterized by an abstract neglect of spirituality. Thus, his seminar The Hermeneutics of the Subject (2005) distinguishes between pre-modern notions of truth conditioned on ethics and spirituality, and the modern idea that it is "knowledge alone" that gives the subject access to truth. The problem with Western philosophy and what he terms the "Cartesian moment" would here be that it constitutes itself as a "pure gaze independent of any private interest, and capable of universality" (Foucault 2005: 125). In modern thought, the knowledge act in itself becomes the sole condition for accessing truth, and thus the relation between the subject and truth becomes a technical issue concerned with methods rather than the structure of the subject involved in this process (2005: 17). With modernity, we have then entered an age where truth does not require subjective change. In contrast to this, parrhēsia is a technology of counter-conduct situated in mundane, spiritual work on the self. In line with the Delphic notion of "know yourself!" (gnothi seauton), it stands for a truth-telling fundamentally linked to the ethical obligation to care for the self (epimeleia heautou) (2005: 10). It is a knowledge conditioned on a spiritual change of the structure of the subject (2005: 15). A central aim in Foucault's later works is to address why Western philosophy came to obscure this ethical origin of truth. Another impulse is to consider new forms of subjectivity in order to restore this dimension of truth. If Foucault then laments the modern reduction of truth-telling, his later work points to the necessity to reinstall some ethical or spiritual element in our understanding of truth. In other words, if counter-conduct is conduct wherein the subject must be transformed to be capable of truth, this transformation will also have to reintroduce some element that embodies these qualities that modern thinking and governance have side-stepped (2005: 12-15).

A closer look on the role of spirituality in AA practice suggests that it is difficult to include AA spirituality in the apparatus of modern abstractness as Foucault describes it. AA spirituality has a very specific place in its discourse, insofar as it is opposed to alcoholism as its solution. As a "spiritual awakening," recovery stands for a process of subjective conversion, but also for another life organized around the practicing of new principles associated with "a power greater than ourselves" (Alcoholics Anonymous 2001: 46, 59, 557). Spirituality here embodies the other of alcoholism, alcoholic identity and alcoholic life. As such spiritual experience is not dependent on any a specific figure of God, but closely tied to the way in which one lives one's life openly in AA, without the principles that protects and maintains the regime of the ego (Alcoholics Anonymous 2001: 64). While AA epistemology contains the description of addiction as a disease of the will, the solution is then not to remedy this will and re-instate the regime of the ego. On the contrary, recognizing that the alcoholic ego, with its sense of omnipotence and will power, is in fact powerless, signals a collapse of "interpretative structure" that the alcoholic has based her life on (Denzin 1993: 114).

This is consistent with Bateson's view that alcoholic drinking in AA discourse is aligned with individualism, will-power, and a "whole epistemology of self-control" (Bateson, 1972: 327). In fact, the idea of control is consistently opposed by AA as 
an essential part of the alcoholic belief that one may someday control drinking and drink like other people (Alcoholics Anonymous 2001: 30). It is this belief that "I can..." resist and control drinking, which defines the dynamics of alcoholic pride and denial (Bateson 1972: 321). As a particular device in the apparatus of alcoholism, pride allows the alcoholic to take the risk of occasionally accepting the challenge to test sobriety as if there was a possibility to win the battle. Hence, alcoholism is a disease run by the will to control the world, and that places the alcoholic in a dis-eased relation of competition with other individuals and societal institutions, that sooner or later turns against the alcoholic and starts to dominate him (Alcoholic Anonymous 2001: 64ff.). The function of the spiritual solution in AA is then to put an end to this belief in the possibility of self-control, to shatter the ego, and admit to an essential powerlessness over alcohol. ${ }^{6}$ Spiritual life is in this sense a collective life, premised on a subjective conversion that interrupts a life based on an antagonism with the world (Bateson 1972; Denzin 1993).

This insistence on spirituality again raises the question about the role of obedience in AA (Bufé 1998). As already stated, AA's practice seems to resist change, and the spiritual solution is clearly one of its non-negotiable corner-stones, and in a sense recovery implies spirituality. Yet, the meaning of spirituality is not a fixed content, and little in AA spirituality reminds of the obedience in pastoral institutions or bureaucratic power in Foucault. One mark of this collective trust is that AA explicitly places the power of formulating the actual content of God in the hands of each member - that is, "We made a decision to turn our will and our lives over to the care of God as we understood Him" (step 3). This emptying of the central authority in the process of recovery is clearly conveyed in the Big Book. Originally being a result of a compromise between the founding groups of AA, in particular the highly Christian milieu of Akron and the near atheist group in New York, the Big Book goes a long way to minimize the use of Christian terminology in talk of the higher power (O'Halloran 2008: 75). If the discourse is still saturated by Christian religion, and terms such as Christ features regularly, there are also strong tendencies to broaden the understanding of what the higher power might mean. This ambition allows for some diversity, and works against the tendency to tie recovery to a predetermined spiritual content. Although we might then point to a strong Christian influence in the discourse, it is also the case that this open form of spirituality blocks any final determination of its content. Rather than a dogmatic knowledge, this suggests a highly contingent discursive content that fits well with AA's self-image of being strictly democratic. ${ }^{7}$ That is, AA appears to enact a spirituality influenced by Christian terminology, without giving the specific knowledge-content of this discourse any unambiguous authority; the crucial point being that spirituality in any form is

\footnotetext{
6 Step 1 "We admitted we were powerless over alcohol - that our lives had become unmanageable".

7 We might compare this to the political theory of Claude Lefort (1988) and in particular his notion of democracy as characterized by a lack of a secure foundation or content. It is not that democracy does not contain content, or, that it is not temporarily hegemonized by specific contents, but that it formally needs to be structured around a certain empty space. Laclau and Mouffe write: "According to Lefort, the radical difference which democratic society introduces is that the site of power becomes an empty space; the reference to a transcendent guarantor disappears, and with it the representation of the substantial unity of society" (2001: 186).
} 
the privileged way of interrupting the authority of individualism as expressed in alcoholic pride.

Likewise, AA's surrender to a greater power does not appear to reinstate a relationship of obedience typical of pastoral ascetics. AA's characterization of God as a "loving God" seems far removed from the terrifying God of judgment typical of the pastoral institution or later versions of asceticism that Foucault takes issue with. AA spirituality contains few signs linking it to discipline, control and guilt, and appears more related to the early forms of Christian parrhēsia and asceticism that Foucault identifies as heavily influenced by Greek asceticism. This early Christian parrhēsia aimed to establish an "openness of heart to God" that Foucault defines as "a transparency of the soul which offers itself to God's sight" (Foucault 2011: 326), and its practices invented a new version of parrēsia characterized by a deep sense of trust and confidence in both God and one's own ability to connect with God. These features resonate with AA spirituality, where the ascetic quality of step work if anything is premised on a relation of hope, promise and love to God, other members of AA and the world.

\section{Conclusion}

The present article has departed from a sense that Foucauldian oriented studies of addiction in general fail to attend to tensions within addiction discourse as embodiments of real struggle and antagonism. I have argued that the use of Foucault is symptomatic of this failure insofar as it neglects central issues that his later work introduces, most importantly in this context, those concerning care of self, parrhēsiastic truth-telling, and counter-conduct. Interpreted as mere extensions of biopolitical governance, alcoholism and other addictions are seen as "diseases of the will" that reproduce power and normalization through therapeutic and subjective knowledge of governmentality. In contrast to such readings, I have suggested that a closer examination of particular practices-here that of Alcoholic Anonymous-might pave the way for a more complex understanding of addiction discourse as a whole. In this context, it is the more limited question of how truth-telling and authority is produced in AA that has been discussed through an analysis of various aspects of its practice. I have argued that none of the discussed aspects of AA practice appear to support biopolitical governance in any straightforward manner. Rather, the analysis has pointed to a number of structural similarities between AA practice and Foucault's notion of parrhēsia. For instance, one might conceive of spiritual work in AA in an analogous way as Heyes has discussed individual, physical exercise in Yoga practices. While increased bodily awareness through Yoga, according to Heyes, operates on the level of individual, its radical contribution to a political theory or practice should not be confused with the exercise of will (Heyes 2018: 541). Similarly, although AA spirituality is clearly linked to individual well-being, it is not reducible to self-improvement and exercise of subjective will-power. Spirituality is the fundamental tactical element of AA's battling with the attitude of resentment, which characterizes the alcoholic lifeworld and relation to others. It is a tool that precisely allows the alcoholic to transcend those "wounded 
attachments" that Heyes with Wendy Brown (1995) argues constitutes one of the greatest dangers for contemporary politics, that is, the tendency to constantly react to external wrongs by way of self-victimization. In this sense, individual spiritual self-discipline or ascetics might be seen as paving the way for acting in the world based on a form of self-knowledge that does not necessarily reproduce the metaphysics of the will that according to critical addiction studies supports neo-liberal processes of responsibilization, and signals a neo-conservative return to moral codes that reinvigorates outmoded elements of modern normativity (Keane 2002; Reay, Attwood and Gooder 2015: 146; Sedgwick 1992; Valverde 1998). If addiction discourse like Eve Sedgwick (1992) rightly has pointed out marks the historical development from a framework that focuses on the problem of substances, to one whose primary object is the personality of the addict/alcoholic, this does not automatically imply an unequivocal progress of governmentality and will-power. Indeed this article has not argued with the notion that AA's work on the self rests on a certain grade of responsibility and desire. But it has claimed that such responsibility and desire is not primarily based on an individualistic, egoistic, or neoliberal discourse, but in an altered subjectivity that might undermine such discourse. As Valverde notes in The Diseases of the Will, medicine early on celebrated the "heroism" of recovering alcoholics, and recognized that curing alcoholism demanded active cooperation and work from the patient in order to be successful (Valverde 1998: 15). Perhaps it is time to, at least minimally, acknowledge the political significance of this early recognition of subjectivity in medicine. And Foucault's late work exactly gives us the tools to conceive of this recognition not solely or necessarily as one that reproduces contemporary biopolitics, but more importantly as a form of knowledge that allows for reinvented forms of truth-telling and processes of counter conduct that promise to interrupt contemporary governance.

Acknowledgements The author would like to thank Tora Holmberg, Maria Törnqvist and David Redmalm for their input on an earlier draft of this article, as well as two anonymous reviewers at Human Studies for their helpful suggestions.

Funding Open Access funding provided by Uppsala University.

Open Access This article is licensed under a Creative Commons Attribution 4.0 International License, which permits use, sharing, adaptation, distribution and reproduction in any medium or format, as long as you give appropriate credit to the original author(s) and the source, provide a link to the Creative Commons licence, and indicate if changes were made. The images or other third party material in this article are included in the article's Creative Commons licence, unless indicated otherwise in a credit line to the material. If material is not included in the article's Creative Commons licence and your intended use is not permitted by statutory regulation or exceeds the permitted use, you will need to obtain permission directly from the copyright holder. To view a copy of this licence, visit http://creativecommons.org/licen ses/by/4.0/.

\section{References}

Anonymous, A. (2018). AA Fact file. New York: Alcoholics Anonymous World Services Inc. Anonymous, A. (2001). The Big book of Alcoholic Anonymous: How thousands of men and women have recovered from alcoholism. New York: Alcoholics Anonymous World Services Inc. 
Bateson, G. (1972). Steps to an ecology of mind. Chicago: University of Chicago Press.

Bech Dyrberg, T. (2016). Foucault on parrhesia: The autonomy of politics and democracy. Political Theory, 44(2), 265-288.

Bufe, C. (1998). Alcoholic Anonymous: Cult or cure? Tucson: Sharp Press.

Brown, W. (1995). States of injury: Power and freedom in late modernity. Princeton: Princeton University Press.

Davidson, A. (2005). Introduction. In M. Foucault (Ed.), Hermeneutics of the subject. Lectures at the Collège de France 1981-1982. New York: Picador.

Dean, T. (2009). Unlimited intimacy: Reflections on the subculture of barebacking. Chicago: Chicago University Press.

Denzin, N. (1993). Alcoholic society: Addiction and recovery of the self. New Brunswick: Transaction Publishing.

Folkers, A. (2016). Daring the truth: Foucault, parrhesia and the genealogy of critique. Theory, Culture and Society, 33(1), 3-28.

Foucault, M. (1985). The history of sexuality, vol 2: Use of pleasure. New York: Pantheon.

Foucault, M. (1997). Ethics: Subjectivity and truth. New York: New Press.

Foucault, M. (2005). Hermeneutics of the subject. Lectures at the Collège de France 1981-1982. New York: Picador.

Foucault, M. (2007). Security, territory, population. Lectures at the Collège de France 1977-1978. New York: Picador.

Foucault, M. (2010). The government of self and others. Lectures at the Collège de France 1982-1983. New York: Picador.

Foucault, M. (2011). The courage of truth: The government of self and others II. Lectures at the Collège de France 1983-1984. New York: Picador.

Fraser, S., Moore, D., \& Keane, H. (2014). Habits: Remaking addiction. Basingstoke: Palgrave MacMillan.

Gros, F. (2011). Course context. In M. Foucault (Ed.), The courage of truth: The government of self and others II, Lectures at the Collège de France 1983-1984. New York: Picador.

Hadot, P. (2009). The present alone is our happiness: Conversations with Jeannie Carlier and Arnold I. Davidson. Stanford: Stanford University Press.

Hardt, M. (2010). Militant life. New Left Review, 64, 151-160.

Heyes, C. (2018). Two kinds of awareness: Foucault, the will, and freedom in somatic practice. Human Studies, 41, 527-544.

Keane, H. (2002). What's wrong with addiction. Melbourne: Melbourne University Press.

Laclau, E., \& Mouffe, C. (2001). Hegemony and socialist strategy. London: Verso.

Lefort, C. (1988). Democracy and political theory. Cambridge: Polity Press.

Luque, A. (2018). Literature of the self in Foucault: Parrhesia and autobiographical discourse. CLCWeb Comparative Literature and Culture, 20(4), 2-9.

Mäkelä, K., Arminen, I., Bloomfield, K., Eisenbach-Stangl, I., Bergmark, K., et al. (1996). Alcoholics Anonymous as a mutual help movement: A study in eight societies. Madison: University of Wisconsin Press.

Mutch, A. (2015). Pastoral power and governmentality: From therapy to self help. Journal for the Theory of Social Behaviour, 46(3), 268-285.

O'Halloran, S. (2008). Talking oneself sober: The discourse of Alcoholics Anonymous. Amherst: Cambria Press.

Oksala, J. (2016). Feminist experiences. Evanston: Northwestern University Press.

Prozorov, S. (2017). Foucault's affirmative biopolitics: Cynic parrhesia and the biopower of the powerless. Political Theory, 45(6), 801-823.

Rabinow, P. (1997). Introduction. In M. Foucault (Ed.), Ethics: Subjectivity and truth. New York: New Press.

Reay, B., Attwood, N., \& Gooder, C. (2015). Sex addiction: A critical history. Cambridge: Polity Press.

Rose, N. (1999). Powers of freedom: Reframing political thought. Cambridge: Cambridge University Press.

Sedgwick, E. K. (1992). Epidemics of the will. In J. Crary \& S. Kwinter (Eds.), Incorporations. London: MIT Press. Cambridge.

Tiebout, H. M. (1947). The problem of gaining cooperation from the alcoholic patient. Quarterly Journal of Studies on Alcohol, 8(1), 47-54.

Valverde, M. (1998). The Diseases of the will. Cambridge: Cambridge University Press. 
White, R. (2014). Foucault on the care of the self as an ethical project and spiritual goal. Human Studies, 37(4), 489-504.

White, W. L. (1998). Slaying the dragon: The history of addiction treatment and recovery in America. Bloomington: Chestnut Health Systems.

Publisher's Note Springer Nature remains neutral with regard to jurisdictional claims in published maps and institutional affiliations. 